\title{
Characterization and androgenic regulation of major mRNAs coding for epididymal proteins in a lizard (Lacerta vivipara)
}

\author{
Y. Courty, F. Morel and J. P. Dufaure \\ Biologie cellulaire Université de Clermont-Fd II et UA 360 CNRS, 24 Av. des Landais, \\ 63170 Aubière, France
}

\begin{abstract}
Summary. During the reproductive period (spring) under the control of testosterone the epididymis of the viviparous lizard secretes a group of major proteins with an approximate $M_{\mathrm{r}}$ of 19000 named $\mathrm{L}$ protein(s). These proteins are recognized by a specific immunoserum and bind to the heads of spermatozoa. During spring, translation in reticulocyte lysate of RNA from secreting epididymis (stage 6) produced 5 immunoprecipitable bands with $M_{r}$ values from 21500 to 25000 . Such synthesis is undetectable during sexual rest in summer (stage 1). The 5 bands disappear when translation is performed in the presence of dog pancreas microsomes although a new band of $M_{\mathrm{r}} 19000$ becomes prominent. This suggests that synthesis of $\mathrm{L}$ protein involves two steps, i.e. synthesis of precursors (L preproteins) followed by a maturation process. At least 11 translation products (including L-preproteins) are involved in annual variations that follow the differentiation of the epididymal epithelial cells and their androgen dependency was studied by castration and in-vitro stimulation by testosterone. In these conditions, testosterone is able to control accumulation of RNA corresponding to $\mathrm{L}$ preproteins and to a translation product of $M_{\mathrm{r}} 29000$.
\end{abstract}

\section{Introduction}

It has been shown in many species that several epididymal glycoproteins can become attached to spermatozoa (rat: Lea et al., 1978; man: Tezon et al., 1985). Although the physiological impacts of these interactions are not fully understood, they are related to sperm maturation. The role of epididymal glycoproteins in membrane stabilization (Eng \& Oliphant, 1978; Thomas et al., 1984) or in the acquisition of the progressive motility of immature spermatozoa (Acott \& Hoskins, 1981) has been demonstrated in some cases. Sperm maturation is androgen-dependent and requires RNA synthesis and epididymal protein synthesis (Orgebin-Crist \& Jahad, 1978). However, very little is known about the modulation of epididymal gene expression by hormones, particularly the genes of secreted proteins (Brooks et al., 1986a, b). The epididymis of the viviparous lizard, Lacerta vivipara, which has a seasonal reproductive cycle, secretes about 15 proteins and soluble glycoproteins which mix with spermatozoa in the spring, the reproductive period. One-dimensional electrophoresis has made it possible to characterize a major band of $M_{\mathrm{r}} 19000$, called the $\mathrm{L}$ protein (Depeiges \& Dufaure, 1981); its synthesis is androgen-dependent (Depeiges et al., 1981a). With an anti-L protein immunoserum, the presence of this protein was detected on the spermatozoa (Depeiges \& Dufaure, 1983), which undergo epididymal maturation in this species (Depeiges \& Dacheux, 1985) as in mammals.

In this work on lizard epididymis, we attempted to characterize the mRNAs that evolve during the annual cycle, or after castration and in-vitro testosterone stimulation, by translation in reticulocyte lysate. In particular, we studied the mRNAs that corresponded to the proteins detected by the anti-L protein immunoserum. 


\section{Materials and Methods}

Animals. Adult viviparous lizard males (Lacerta vivipara) were collected in the Massif Central (France) during their active period (March-September). Castration was performed after ether anaesthesia. Lizards were kept for 7, 15 or 30 days. The animals were killed by decapitation. The epididymides were excised, immediately frozen in liquid nitrogen, and then stored at $-80^{\circ} \mathrm{C}$.

Isolation of total and poly $(A)$ RNA. Epididymal tissue of 100-500 mg was used to prepare total RNA (Cathala et al., 1983). Briefty, frozen epididymides were homogenized in $0.7-3.5 \mathrm{ml} 3 \mathrm{M}$-guanidium monothiocyanate, $50 \mathrm{~mm}-$ Tris- $\mathrm{HCl}$, pH 7.5, $10 \mathrm{~mm}$-EDTA and $10 \% \beta$-mercaptoethanol. Total RNA was precipitated using $3 \cdot 5 \mathrm{M}-\mathrm{LiCl}$ at $4 . \mathrm{C}$ for $36 \mathrm{~h}$. After centrifugation at $11000 \mathrm{~g}$ for $90 \mathrm{~min}$ followed by washing with $3 \mathrm{M}-\mathrm{LiCl}$, the pellet frozen in $10 \mathrm{~mm}$ Tris $-\mathrm{HCl}, \mathrm{pH} 7 \cdot 5,1 \mathrm{~mm}$-EDTA and $0 \cdot 1 \%$ SDS was redissolved by vortexing during thawing. RNA was recovered by ethanol precipitation after removal of proteins with phenol-chloroform-isoamyl alcohol mixture (15:14:1, by vol.).

Poly (A) RNA was prepared using the oligo (dt) cellulose chromatography method of Aviv \& Leder (1972). RNA was dissolved in sterile water and heated to $65^{\circ} \mathrm{C}$ for $5 \mathrm{~min}$. It was applied three times to the column after adding 2 volumes of loading buffer, $20 \mathrm{~mm}-$ Tris- $\mathrm{HCl} \mathrm{pH} 7 \cdot 5,0.5 \mathrm{M}-\mathrm{LiCl}, 1 \mathrm{~mm}-\mathrm{EDTA}$ and $0.1 \%$ SDS. After washing oligo(dt)-bound RNA with binding buffer, the poly (A) RNA was eluted with 10 mm-Tris-HCl pH 7.5, 1 mM-EDTA, $0.05 \%$ SDS and recovered by ethanol precipitation. Typically, I-2 mg total RNA were applied to an $80 \mathrm{mg}$ column of oligo-(dt)-cellulose type 7 (Pharmacia France S.A., Bois D'Arcy, France).

Translation of RNA and immunoprecipitation of labelled proteins. In-vitro translation of total RNA (10 $\mu \mathrm{g})$ or poly (A) RNA ( $2 \mu \mathrm{g})$ was carried out in rabbit reticulocyte lysate (N 90, Amersham France, Les Ulis, France) in the presence of $10 \mu \mathrm{Ci}\left[{ }^{35} \mathrm{~S}\right]$ methionine (sp. act. $1000 \mathrm{Ci} / \mathrm{mmol}$ : Amersham). Incubation with human placental ribonuclease inhibitor (RNAsine $1 \mathrm{U} / \mu \mathrm{l}$ : Amersham) lasted for $60 \mathrm{~min}$ at $37^{\circ} \mathrm{C}$ according to the manufacturer's instructions. Translations of poly (A) RNA $(2 \mu \mathrm{g})$ were also achieved in the presence of dog pancreas microsomes (Amersham) in identical conditions except that one-third of the final volume $(30 \mu \mathrm{l})$ was occupied by microsomes.

Immunoprecipitation of labelled proteins is usually performed on $3 \times 10^{5} \mathrm{~d}$.p.m. (determined by trichloracetic acid (TCA) precipitation) by adding $20 \mu \mathrm{l}$ undiluted anti-L protein serum. After an incubation of $2 \mathrm{~h}$ at room temperature with shaking, $20 \mathrm{mg}$ protein A Sepharose (Pharmacia) in $80 \mu \mathrm{l} 0 \cdot 12 \mathrm{M}$-Tris- $\mathrm{HCl} \mathrm{pH} 7 \cdot 2,1 \%$ Triton X-100 and $1 \%$ BSA were added and samples were incubated for $1 \mathrm{~h}$ as described. The immunoprecipitates were washed 3 times with the detergent solution and their proteins eluted with $40 \mu \mathrm{l} 2 \% \mathrm{SDS}, 5 \% \beta$-mercaptoethanol in $0 \cdot 12 \mathrm{M}-\mathrm{Tris}-\mathrm{HCl}$ $\mathrm{pH} 7.2$ by boiling for $5 \mathrm{~min}$.

Organ culture and short in-vitro incubations. Explants came from animals killed 5 weeks after castration. The method used has been previously described (Dufaure \& Gigon, 1975). The culture medium was Medium 199 supplemented with $10 \%$ calf serum (Institut Pasteur, Paris, France). Cultures were maintained at $30^{\circ} \mathrm{C}$ for 10 days in the presence or absence of testosterone $(150 \mathrm{~nm})$. The gas phase was $5 \% \mathrm{CO}_{2}$ in air. The culture medium was changed every 2 days. Then fragments of the epididymides were frozen and stored as previously described.

In-vitro labelling of normal or cultured epididymal tissue was performed on 4 organs in 1 ml Eagle's minimum essential medium (MEM) without methionine (Gibco-BRL, Cergy-Pontoise, France) in the presence of $40 \mu \mathrm{Ci}$ $\left[{ }^{35} \mathrm{~S}\right]$ methionine (sp. act. $1000 \mathrm{Ci} / \mathrm{mmol}$ : Amersham) for $4 \mathrm{~h}$ at $30^{\circ} \mathrm{C}$ in a $\mathrm{CO}_{2}$-enriched atmosphere. Then, epididymides were rinsed with $0.12 \mathrm{M}$-Tris- $\mathrm{HCl} \mathrm{pH} 7.2$ at $4^{\circ} \mathrm{C}$ and homogenized in the same buffer with $0.1 \%$ SDS for electrophoresis loading.

Protein electrophoresis and fiuorography. One dimensional electrophoreses were performed in the presence of SDS in $12.5 \%(\mathrm{w} / \mathrm{v})$ acrylamide- $0.1 \%$ bisacrylamide in Tris-glycine buffer $\mathrm{pH} 8.3$ (Laemmli, 1970). For in-vitro labelling or translation 50000 and 300000 d.p.m., determined by TCA precipitations, respectively were loaded. Fluorography of the gels was performed using PPO-DMSO (20\% PPO in DMSO, w/v) as an enhancer. After drying, they were autoradiographed for 5-10 days at $-80^{\circ} \mathrm{C}$ on an X-Omat film (Kodak, Rochester, NY, U.S.A.) in the presence of intensifying screens (Dupont Cronex $\mathrm{Li}+$ : Wilmington, DE, U.S.A.).

Radioimmunoassay. The procedure for measuring testosterone in the tissues of the lizard has been described previously (Courty \& Dufaure, 1982; Dufaure et al., 1986). Briefly, epididymides were homogenized and extracted with iso-octane/ethyl acetate $(7: 3, \mathrm{v} / \mathrm{v})$. The extracts were chromatographed onto celite columns. The testosterone fractions were redissolved in a testosterone antiserum (Veyssiere et al., 1976) diluted to 1:40000 in phosphatebuffered saline with $1 \%$ gelatin, and incubated overnight at $4{ }^{\circ} \mathrm{C}$. Free and antibody-bound steroids were separated with the dextran-charcoal procedure. The supernatant was counted with a scintillator spectrophotometer (Intertechnique). Accuracy, determined by adding known amounts of testosterone, was $4 \%$. The intra- and inter-assay variations, determined by repeated measurements of other biological samples, were $8 \%$.

\section{Results}

\section{Characterization of the L preproteins}

Epididymides in hypersecretory activity (stage 6, according to Dufaure $e$ t al., 1986) were used to prepare poly (A) RNA. The translation of $2 \mu \mathrm{g}$ poly (A) RNA into reticulocyte lysate led to a series 
(a) (b) (c)

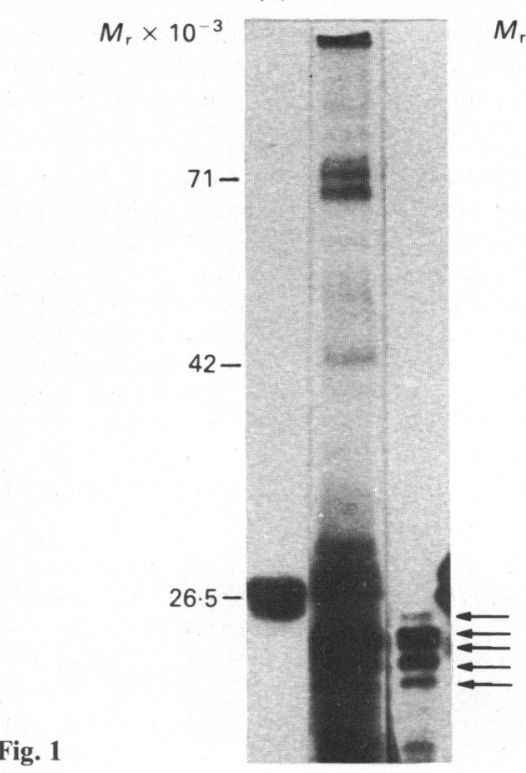

(a) (b)

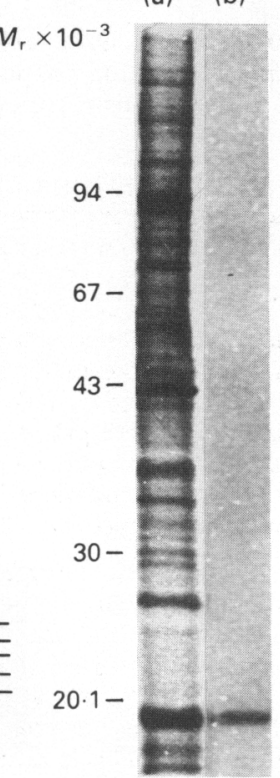

Fig. 2

Fig. 1. Fluorography analysis of epididymal proteins translated in rabbit reticulocyte lysate from poly (A) RNA of stage 6: (a) products translated by the lysate without added RNA; (b) translated products from $2 \mu \mathrm{g}$ poly (A) RNA; (c) immunoprecipitated proteins translated from $2 \mu \mathrm{g}$ poly (A) RNA.

Fig. 2. Fluorography analysis of $\left[{ }^{35}\right.$ S $]$ methionine-labelled soluble proteins synthesized by the lizard epididymis during short in-vitro incubations. Profile during reproductive period (stage 6): (a) total proteins; (b) immunoprecipitated protein with anti-L immunoserum.

of protein bands (Fig. 1b) most of which had an $M_{\mathrm{r}}<30000$. Five were immunoprecipitated with the anti-L protein immunoserum: $M_{\mathrm{r}} 25000,24000,23500,22500$ and 21500 (Fig, 1c). When this pattern was compared to the pattern obtained in tissue minces (Figs $2 \mathrm{a} \& 2 \mathrm{~b}$ ), the immunoprecipitated translation products had mobilities different from those of $\mathrm{L}$ protein synthesized in tissue minces. We presumed that these translation products were various precursors of the $\mathrm{L}$ protein. To verify this hypothesis, in-vitro translation was performed in the presence of dog pancreas membranes to process the $\mathrm{L}$ precursors (Fig. 3). Adding microsomal membranes resulted in the appearance of a new translation product of $M_{\mathrm{r}} 19000$ which was immunoprecipitated by the $\mathrm{L}$ immunoserum, and in a concomitant loss of most of the products of higher molecular weight (Fig. 3h).

\section{Changes in the $m R N A s$ during the reproductive cycle}

The lizard epididymis has an annual cycle that undergoes very great morphological and biochemical modifications. Ten stages have been defined on the basis of histological aspects (Dufaure et al., 1986). These stages characterize the 5 main phases of differentiation (Fig. 4). To characterize the mRNAs that evolve during this differentiation, we prepared total RNA at different times during the annual cycle. A comparison of the extraction efficiency $(0.8 \mathrm{mg} / \mathrm{g}$ from Phase II epididymis; $2 \cdot 5-3 \mathrm{mg} / \mathrm{g}$ from Phase IV epididymis) shows that there is a marked change in the total RNA tissue concentrations. Translatable RNA species were examined by translating them in a 

(a)
(b) (c)
(d) (e) (f)
(g) (h)

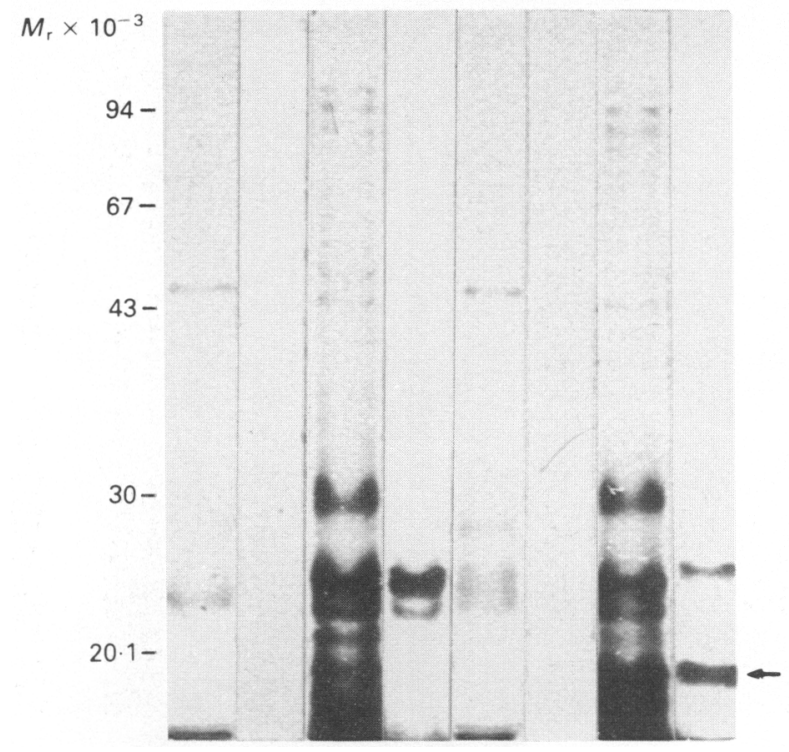

Fig. 3. Comparison of products from poly (A) RNA (stage 6) translated in the absence (lanes a, $b, c, d$ ) or presence (lanes $e, f, g, h$ ) of dog pancreas microsomes. Lanes (a) and (e): no added RNA; (b) and (f): immunoprecipitated products obtained in the same conditions as (a) and (e); lanes (c) and (g): proteins translated by the reticulocyte lysate from $2 \mu \mathrm{g}$ poly (A) RNA; lanes (d) and (h): immunoprecipitated products obtained as (c) and (g), respectively.

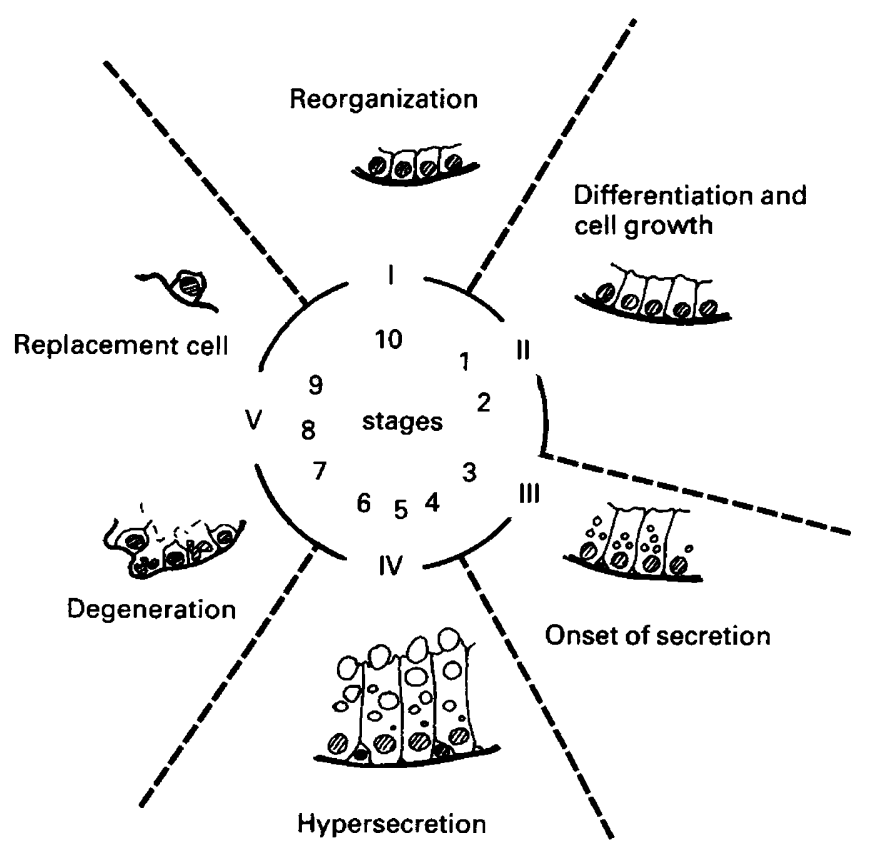

Fig. 4. Schematic cycle of the lizard epididymis. The 10 stages described by Dufaure $e t$ al. (1986) characterize 5 main phases of differentiation (phases I to V). 


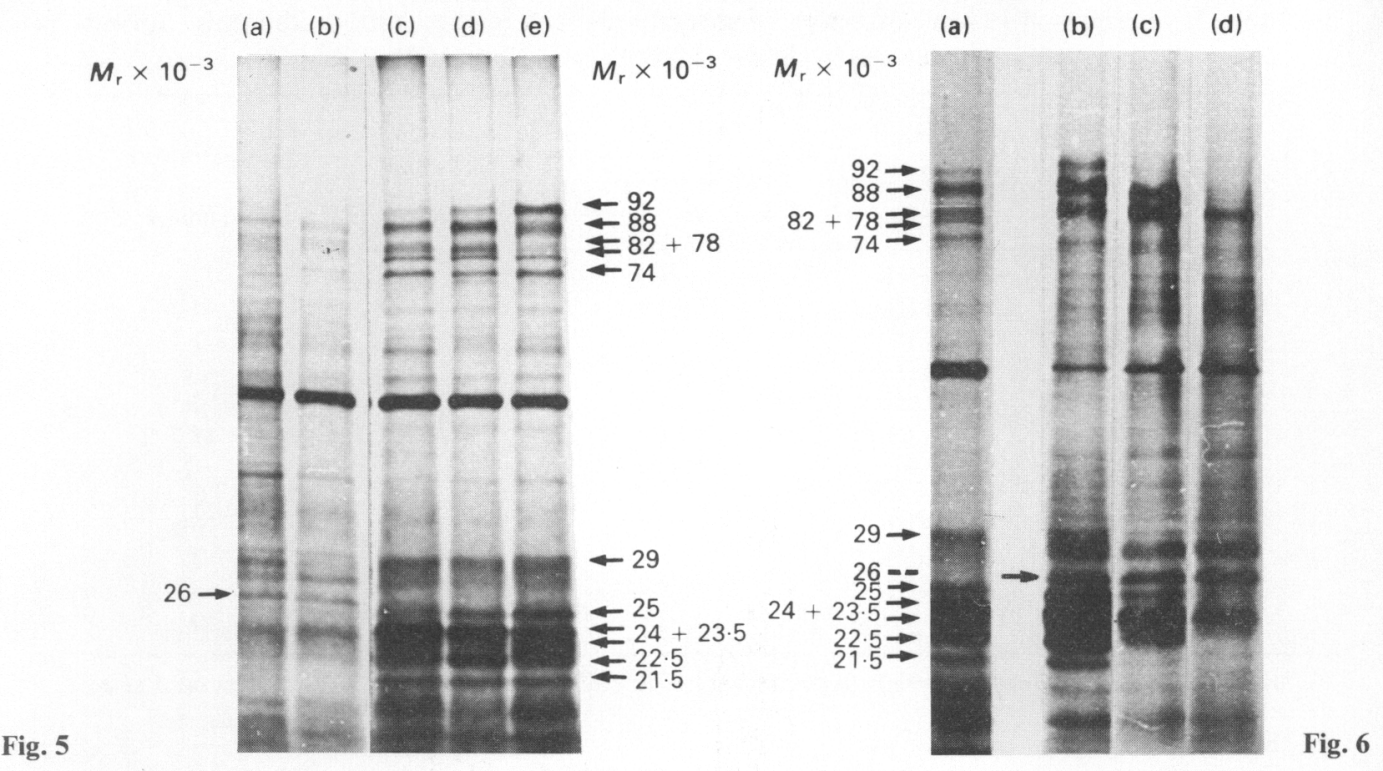

Fig. 5. Fluorography analysis of products translated in rabbit reticulocyte lysate from total epididymal RNA prepared during the annual cycle of the lizard: (a) stage 1, phase II; (b) stage 3 , phase III; (c) stage 5, phase IV; (d) stage 6, phase IV; (e) stage 7, early phase V. Distinguishable products are arrowed.

Fig. 6. Fluorography analysis of products translated from total epididymal RNA prepared at different times after stage 6 castration: (a) normal stage 6; (b) 1 week after castration; (c) 2 weeks after castration; (d) 5 weeks after castration.

cell-free system and by analysing the patterns of radiolabelled translation products on SDSpolyacrylamide gels (Fig. 5). Densitometer scans of the fluorographs (Table 1) revealed changes in translatable RNAs during the annual cycle. These differences resulted from the disappearance of components, from changes in the relative amounts of components, and from the appearance of new components. For example, $L$ components of $M_{\mathrm{r}} 25000,24000,22500$ and 21500 which were only faintly present in translations of stages 1 and 3, represented major labelled species in translations of stages 5, 6, and 7. Another component, $M_{\mathrm{r}} 26000$, was present in stages 1 and 3 and disappeared during cell hypertrophy and secretion (stages 5 and 6). All these components are classified in Table 1 according to their molecular weight. The changes in relative amounts evaluated by densitometer analysis are from 3 to 20 depending on the component studied.

Epididymal testosterone concentrations were examined by radioimmunoassay. Two increases in concentrations were observed: between stages 10 and $1(20 \cdot 1 \pm 3 \cdot 1 \mathrm{ng} / \mathrm{g}, 69 \cdot 3 \pm 10 \cdot 3 \mathrm{ng} / \mathrm{g}$ respectively) and between stages 3 and $6(85 \cdot 7 \pm 14.4 \mathrm{ng} / \mathrm{g}, 256 \pm 28 \mathrm{ng} / \mathrm{g}$ respectively). A comparison with Table 1 indicates that most of the messengers reached maximal levels when testosterone was highest.

\section{Effects of castration}

We castrated a series of lizards in stage 6 . The effects of castration were noted over a 5-week period by in-vitro translation of total RNA (Fig. 6). A progressive decrease in the various components classified above was observed including the L-preproteins (Table 1; Fig. 6). By the week after 
Table 1. Changes in relative amounts of specific mRNAs in the lizard epididymis, during the annual cycle and 5 weeks after castration

\begin{tabular}{|c|c|c|c|c|}
\hline \multirow{3}{*}{$\begin{array}{l}\text { Translation } \\
\text { products } \\
\left(M_{\mathrm{r}}\right)^{*}\end{array}$} & \multicolumn{3}{|c|}{ Annual cycle } & \multirow{3}{*}{$\frac{\text { Castration }}{\text { Fold changes } \ddagger}$} \\
\hline & \multirow{2}{*}{$\begin{array}{l}\text { Phases with minimal } \\
\text { amounts }\end{array}$} & \multirow{2}{*}{$\begin{array}{l}\text { Phases with maximal } \\
\text { amounts } \dagger\end{array}$} & \multirow[b]{2}{*}{ Fold changes $\ddagger$} & \\
\hline & & & & \\
\hline 92000 & II and III & EV & 17 & 14 \\
\hline 88000 & II and III & IV & 5 & $4 \cdot 5$ \\
\hline 82000 & II and III & IV & 6 & 1.7 \\
\hline 78000 & II and III & IV & 3 & $\S$ \\
\hline 74000 & II and III & EV & 7 & $3 \cdot 5$ \\
\hline 29000 & II and III & EV & 5 & $18 \cdot 5$ \\
\hline 26000 & IV and $V$ & II and III & $>15$ & 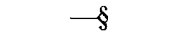 \\
\hline 25000 & II & EV & 9 & 8 \\
\hline 24000 & II and III & IV & 10 & $10 \cdot 5$ \\
\hline 23500 & II and III & EV & 5 & 2 \\
\hline 22500 & II and III & IV & 20 & 18 \\
\hline 21500 & III & IV & 20 & 20 \\
\hline
\end{tabular}

*Relative amounts of each translation product were determined by scanning fluorographs on a laser densitometer.

$\dagger \mathrm{EV}=$ early phase $\mathrm{V}$.

¥Determined between the two extreme measurable values.

$\$$ Not determined; minimal amount detectable.

(a) (b) (c) (d)

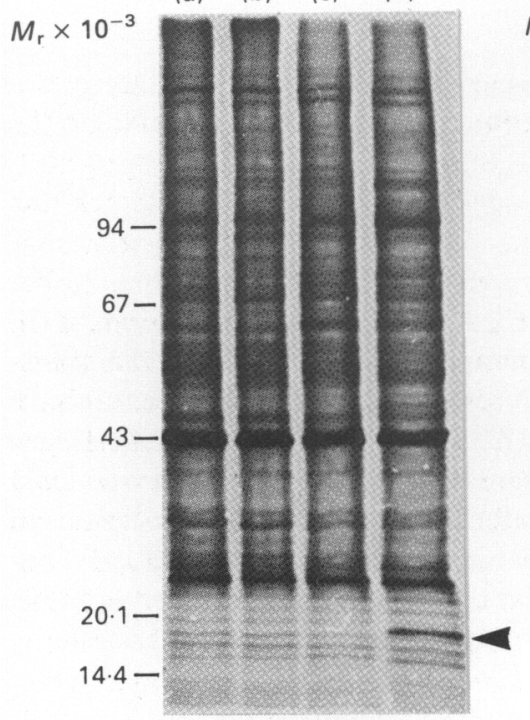

(a)

(b) (c)

(d)

$M_{r} \times 10^{-3}$

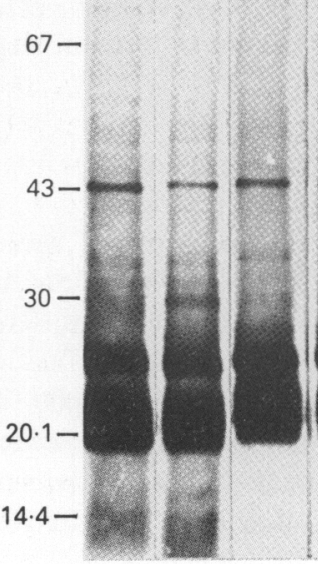

(e)

(f)

(g)

(h)

Fig. 7. Fluorography analysis of newly synthesized proteins after organotypic culture: (a) 5-day culture without testosterone; (b) 5-day culture with testosterone (150 nM); (c) 10-day culture control; (d) 10-day culture with testosterone (150 nM). The $\mathrm{L}$ protein is arrowed.

Fig. 8. Fluorography analysis of products translated from total epididymal RNA prepared after organotypic culture: (a) 5-day culture without testosterone; (b) 5-day culture with testosterone (150 nM); the $M_{\mathrm{r}} 29000$ product is arrowed; (c) 10-day culture without testosterone; (d) 10-day culture with testosterone $(150 \mathrm{nM})$; (e) immunoprecipitation with $\mathrm{L}$ immunoserum of products obtained as for (a); (f) immunoprecipitation of products obtained as for (b); (g) immunoprecipitation of products obtained as for (c); (h) immunoprecipitation of products obtained as for (d); the $M_{\mathrm{r}} 24000 \mathrm{~L}$-preprotein is arrowed. 
castration, a component of $M_{\mathrm{r}} 26000$ appeared and then remained high for the rest of the experiment. The $M_{\mathrm{r}} 78000$ band was no longer visible at 1 week after castration. The $M_{\mathrm{r}} 82000$ band did not appear to change during the 5-week period after castration.

\section{Effects of testosterone administration in vitro}

To study the role that testosterone could play in controlling all these changes, epididymides of animals castrated 5 weeks earlier were grown in organ culture with or without 150 nM-testosterone. After 5 and 10 days of culture, some epididymides were labelled in vitro in the presence of $\left[{ }^{35}\right.$ S $]$ methionine. Others were used for total RNA extractions. Monodimensional gel electrophoresis and fluorography revealed differences in patterns of newly synthesized proteins (Fig. 7). Epididymides treated with testosterone for 10 days developed a band of $M_{\mathrm{r}} 19000$ containing the $\mathrm{L}$ protein (Fig. 7d). In the translation patterns (Fig. 8) the $M_{\mathrm{r}} 29000$ component appeared in tissue grown for 5 days in the presence of testosterone (150 nM) (Fig. $8 \mathrm{~b}$ ). The other components were not clearly detectable with the method used. We treated the translation products with anti-L immunoserum and precipitated the rabbit IgG with the protein A Sepharose. When the immune complex from samples treated with testosterone for 10 days was dissociated and analysed on an SDS gel, it contained a component of $M_{\mathrm{r}} 24000-23500$ (Fig. 8h). This component was not detectable in the other samples.

\section{Discussion}

We have previously established with monodimensional electrophoresis that the lizard secretes a major component of $M_{\mathrm{r}} 19000$ called the $\mathrm{L}$ protein. The synthesis of this protein depends on the presence of androgens (Depeiges et al., 1981a). An antibody to the $\mathrm{L}$ protein was raised using an $\mathrm{L}$ polypeptide purified by non-denaturing electrophoresis (Depeiges et al., 1981b). In this work, the antibody was used to identify specific translation products, and 5 bands were detected by immunoprecipitation. In-vitro translation is well known to give a bias towards the mRNAs for the smaller proteins and therefore the observed patterns do not give the true frequencies of these mRNAs. In this work, this bias was seen more in the poly (A) RNA translations than in the total RNA translations. Recent results obtained with two-dimensional gel electrophoresis (unpublished data) have shown that the $\mathrm{L}$ protein is synthesized as at least 10 isoforms. These isoforms appear as isoelectric variants of the same protein. From these results and, therefore, from specificity tests conducted elsewhere (Depeiges et al., 1981 b), the presence of different bands detected by immunoprecipitation in translation products does not seem to be the consequence of an artefact due to the antibody, but rather reflects polymorphism of the L-protein. The detected polypeptides had mobilities on SDSPAGE different from those of the authentic proteins synthesized in tissue minces. Numerous secretory proteins have been shown to be synthesized as presecretory proteins containing an $\mathrm{NH}_{2}$ extension of 15-30 hydrophobic amino acid residues when their mRNAs are translated in a cellfree system in the absence of microsomal membranes (Milstein et al., 1972; Blobel \& Dobberstein, 1975; Davis \& Tai, 1980). These presecretory proteins are processed by an endopeptidase localized in the granular endoplasmic reticulum. This operation is reconstituted when translation occurs in the presence of dog pancreas microsomes. Translation of lizard epididymal mRNAs in the presence of microsomes processed immunoprecipitable polypeptides to proteins which have molecular weights and antigenic specificities similar to those of the $L$ proteins. These results suggest that the $L$ proteins are synthesized as preproteins and are consistent with the $L$ proteins being a secretory product. In the rat epididymis, a major secretory protein of $M_{\mathrm{r}} 19000$ is synthesized as preprotein of $M_{\mathrm{r}} 21000$ (D'Agostino et al., 1980). The excised parts are larger in lizard L preproteins (from 3000 to 6000 ) and have unusual lengths for signal peptides. 
Androgenic mRNA regulations in the epididymis have not been investigated as much as in other models, namely the kidney, the prostate and seminal vesicles. In these models, androgens regulate gene expression at transcriptional and at post-transcriptional levels (Page \& Parker, 1982; Berger et al., 1986). In the rat epididymis, testosterone would regulate specific protein synthesis via mRNA availability (D'Agostino et al., 1980). However, it has been suggested that other factors present after castration could prevent the translation of an mRNA coding for a protein of $M_{\mathrm{r}}$ 18500 (Brooks et al., 1986a). In the present study, we have shown that the amounts of various mRNA species virtually undetectable in the non-secreting epididymal cells (stage 1) increase with the occurrence of high concentrations of tissue androgens. Translation analysis indicates a clear reduction in concentrations of various described mRNAs at 5 weeks after castration. The reduction patterns are not the same for the different mRNA species. This could be due to the differential sensitivities of mechanisms that control the cellular concentrations of these mRNAs. The present study attempted to induce expression of major mRNAs by androgen administration in vitro to the epididymis at 5 weeks after castration. This was successful only for some L-mRNAs and for other mRNA species. This cell-free translation study did indicate that androgens stimulate at least some mRNA species within the lizard epididymis. In regulating specific protein synthesis via mRNA availability, the action of testosterone in the lizard epididymis partly resembles what occurs in the rat epididymis (D'Agostino et al., 1980).

An mRNA corresponding to a translation product of $M_{\mathrm{r}} 26000$ disappears with the onset of high concentrations of tissue androgens; it reappeared 1 week after castration. These results indicate that other factors control gene expression in the lizard epididymis. In mammals, the involvement of non-androgenic testicular factors has been suggested to explain variations in the synthesis of some epididymal proteins (Jones et al., 1980; Brooks, 1983).

In-vitro translation analysis is not as sensitive or quantitative as hybridization analysis. That is why we have recently synthesized and cloned epididymal cDNAs (Courty et al., 1986). The availability of a cDNA probe for the $\mathrm{L}$ proteins will allow us to investigate the mechanisms described in this study in more detail.

This work was supported by a grant from CNRS (ATP 8305 \& 6933: Organisation et expression du genome) and by the Fondation pour la Recherche Medicale.

\section{References}

Acott, T.C. \& Hoskins, D.D. (1981) Bovine sperm forward motility protein: Binding to epididymal spermatozoa. Biol. Reprod. 24, 234-240.

Aviv, H. \& Leder, P. (1972) Purification of biologically active globin messenger RNA by chromatography on oligothymidylic acid-cellulose. Proc. natn. Acad. Sci. U.S.A. 69, 1408-1412.

Berger, F.G., Loose, D., Meisner, H. \& Watson, G. (1986) Androgen induction of messenger RNA concentrations in mouse kidney is post-transcriptional. Biochemistry, N.Y. 25, 1170-1175.

Blobel, G. \& Dobberstein, B. (1975) Transfer of proteins across membranes. I Presence of proteolytically processed and unprocessed nascent immunoglobulin light chains on membrane-bound ribosomes of murine myeloma. J. cell Biol. 67, 835-851.

Brooks, D.E. (1983) Effect of androgens on protein synthesis and secretion in various regions of the rat epididymis as analysed by two-dimensional gel electrophoresis. Molec. cell. Endocrinol. 29, 255-270.

Brooks, D.E., Means, A.R., Wright, E.J., Singh, S.P. \&
Tiver, K.K. (1986a) Molecular cloning of the cDNA for two major androgen-dependent secretory proteins of 18.5 kilodaltons synthesized by the rat epididymis. J. biol. Chem. 26, 4956-4961.

Brooks, D.E., Means, A.R., Wright, E.J., Singh, S.P. \& Tiver, K.K. (1986b) Molecular cloning of the cDNA for androgen-dependent sperm-coating glycoproteins secreted by the rat epididymis. Eur. J. Biochem. 161, 13-18.

Cathala, G., Savouret, J.F., Mendez, B., West, B.L., Karin, M., Martial, J.A. \& Baxter, J.D. (1983) A method for isolation of intact translationally active ribonucleic acid. DNA 2, 329-335.

Courty, Y. \& Dufaure, J.P. (1982) Circannual testosterone, dihydrotestosterone and androstanediols in plasma and testis of Lacerta vivipara, a seasonally breeding viviparous lizard. Steroids 39, 517-529.

Courty, Y., Morel, F. \& Dufaure, J.P. (1986) Realisation d'une banque d'ADNc correspondant à des protéines androgéno-dépendantes de l'épididyme de lézard. $C$. r. hebd. Séanc. Acad. Sci., Paris, 302, 647-650. 
D'Agostino, A., Jones, R., White, R. \& Parker, M.G. (1980) Androgenic regulation of messenger RNA in rat epididymis. Biochem. J. 190, 505-512.

Davis, B.D. \& Tai, P.C. (1980) The mechanism of protein secretion across membranes. Nature, Lond. 283, 433-438.

Depeiges, A. \& Dacheux, J.L. (1985) Acquisition of sperm mobility and its maintenance during storage in the lizard, Lacerta vivipara. J. Reprod. Fert. 74, 23-27.

Depeiges, A. \& Dufaure, J.P. (1981) Major proteins secreted by the epididymis of Lacerta vivipara, identification by electrophoresis of soluble proteins. Biochem. Biophys. Acta. 667, 260-266.

Depeiges, A. \& Dufaure, J.P. (1983) Binding to spermatozoa of a major soluble protein secreted by the epididymis of the lizard Lacerta vivipara. Gamete Res. 5, 401-406.

Depeiges, A., Betail, G. \& Dufaure, J.P. (1981a) Time course of appearance in vivo and in vitro of a specific epididymal protein controlled by testosterone. Biol. Cell. 42, 49-56.

Depeiges, A., Betail, G. \& Dufaure, J.P. (1981b) Caracterisation immunochimique d'une protéine majeure sécrétée par l'epididyme de lézard. C. r. hebd. Séanc. Acad. Sci., Paris 292, 211-216.

Dufaure, J.P. \& Gigon, A. (1975) Action des hormones androgènes sur l'épididyme d'un Reptile lacertilien, Lacerta vivipara Jacquin. Effets de la testostérone et de ses principaux métabolites en culture organotypique. Gen. comp. Endocrinol. 25, 112-120.

Dufaure, J.P., Courty, Y., Depeiges, A., Mesure, M. \& Chevalier, M. (1986) Evolution and testosterone content of the epididymis during the annual cycle of the lizard Lacerta vivipara. Biol. Reprod. 35, 667-675.

Eng, L.E. \& Oliphant, G. (1978) Rabbit sperm reversible decapacitation by membrane stabilization with a highly purified glycoprotein from seminal plasma. Biol. Reprod. 19, 1084-1094.
Jones, R., Brown, C.R., Von Glos, K.L. \& Parker, M.G. (1980) Hormonal regulation of protein synthesis in the rat epididymis. Characterization of androgendependent and testicular fluid-dependent proteins Biochem. J. 188, 667-676.

Laemmli, U.K. (1970) Cleavage of structural proteins during the assembly of the head of bacteriophage $T_{4}$. Nature, Lond. 227, 680-685.

Lea, O.A., Petruzz, F. \& French, F.S. (1978) Purification and localization of acidic epididymal glycoprotein (AEG): sperm coating protein secreted by the rat epididymis. Int. J. Androl., Suppl. 2, 592-607.

Milstein, C., Brownlee, G.G., Harrison, T.M. \& Mathews, M.B. (1972) A possible precursor of immunoglobin light chains. Nature, New Biol. 239, $117-120$.

Orgebin-Crist, M.C. \& Jahad, N. (1978) The maturation of rabbit epididymal spermatozoa in organ culture: inhibition by antiandrogens and inhibitors of ribonucleic acid and protein synthesis. Endocrinology 103, 46-53.

Page, M.J. \& Parker, M.G. (1982) Effect of androgen on the transcription of rat prostatic binding protein genes. Molec. cell. Endocr. 27, 343-355.

Tezon, J.G., Rameller, E., Cameo, M.S., Vasquez, M.H. \& Blaquier, J.A. (1985) Immunochemical localization of secretory antigens in the human epididymis and their association with spermatozoa. Biol. Reprod. 32, $591-598$.

Thomas, T.S., Reynolds, A.B. \& Oliphant, G. (1984) Evaluation of the site of synthesis of rabbit sperm acrosome stabilizing factor using immunocytochemical and metabolizing techniques. Biol. Reprod. 30, 693-705.

Veyssiere, G., Berger, M., Jean Faucher, C., De Turckheim, M. \& Jean, C. (1976) Levels of testosterone in the plasma, gonads and adrenals during fetal development of the rabbit. Endocrinology 99, 1263-1268.

Received 9 March 1987 